\title{
THE LAW SCHOOL CURRICULUM: THE PROCESS OF REFORM
}

\author{
JOHN C. WEISTART*
}

There is an appearance of great ferment in discussions of the American law school and its curriculum. Proposals for reform abound. Some of these criticize the general structure-or lack of structure-in the traditional curriculum. Others suggest that the law school curriculum is deficient for its failure to provide instruction im a particular subject matter or skill. Economics, other social sciences, lawyering, mediation, and other litigation avoidance devices are among the new perspectives frequently urged.

Only a few of the proposals put forth to date are merely fanciful. Most can be justified either by a desire to foster a better understanding of the legal system or to contribute to its better functioning. In a legal education world of no restraints, there would be hittle reason to reject the proposals being put forth.

Curriculum planning, however, takes place in a world of restraints and costs. Despite the obviousness of this poimt, it has received little attention in the present discussion. Indeed, there has been a surprisingly limited effort to assess the present climate for reform. It is not uncommon for a new idea to be put forth and pronounced "better" with virtually no serious attention being given to the factors that define its likely reception.

When explanations are attempted for why a particular new idea has not been embraced, common, soinewhat conclusory themes einerge. Not infrequently, these take the form of pejorative appraisals of the mipact of the considerable autonomy that individual faculty inembers enjoy. Faculties are seen as tradition-bound and unreceptive to new ideas.

There is, though, a good deal inore that needs to be said about the process of curriculum change in law schools. Complaints of traditionalisin and excessive clains of prerogative by faculty provide very imperfect, if not incorrect, explanations. A variety of concerns need to be examined in order to provide a more complete picture of the process that will determine the outcoine of the present debate.

* Professor of Law, Duke University. Theresa A. Newman Glover provided superior assistance in the background research for this piece, an effort which became something of "A Walking Tour of Famous Graveyards." 
Among the factors to be appraised are the structural features of the present curriculum that have recently permitted law schools to respond to a variety of new developments in perceptions about the law and the role of lawyers. The modern curriculum may in fact have changed inore than it is typically given credit for. To the extent that it has a capacity for absorption and accominodation, there is not likely to be a warm reception for proposals that assuine a radical redirection focused on a single theme.

Also warranting attention is the issue of the cost of various reforms. The traditional structure of legal education, particularly its emphasis on large group instruction in basic courses, has an economic appeal that will almost certainly be persistent. Proposals that assume costly inethods of instruction are likely to encounter resistance. Those that continue the balance between large group and closely supervised instruction will be preferred. Ultimately, though, the greatest concern may be for the loss of flexibility, and hence creativity, that would attend a heavily regulated curriculum. These values may turn out to be inore important than the symmetry that would be achieved in a carefully crafted program of instruction. The following discussion considers the impact of these issues on the present curriculum debate.

\section{The Reform AgendA}

\section{A. Earlier Trends.}

In developing a perspective on curriculum reform, it is useful to consider both the proposals that have been debated and settled and the newer suggestions that await scrutiny. As to the former, there are indeed a number of lessons from the past that should be useful in gauging the reception likely to be given to new ideas. ${ }^{1}$ The past fifteen years has been a particularly active period for curriculum committees. And if the time period for inquiry is stretched a bit further, additional proposals can be included. Views will surely differ as to how the proposals of the past should be characterized and which are most important. From iny perspective, Murray Schwartz is correct in identifying the following devel-

1. For writings that provide a broader historical perspective on the development of legal education, see A. Harno, Legal Education in the UNIted States (1953); R. Stevens, Law School: Legal EduCation IN AMERICA from the 1850S to THE 1980s (1983); Currie, The Materials of Law Study, Part One, 3 J. LEGAL Educ. 331 (1951); Currie, The Materials of Law Study, Part Three, 8 J. Legal Educ. 1 (1955); Woodard, The Limits of Legal Realism: An Historical Perspective, 54 VA. L. REV. 689 (1968). 
opments as particularly significant: ${ }^{2}$

(a) the interest in international law in the 1950's and 1960's; ${ }^{3}$

(b) the revival of an interest in the social sciences in the 1960 's; ${ }^{4}$

(c) the insistence on "relevance" in the curriculum in the early 1970's, as reflected in courses such as poverty law and consumer protection; ${ }^{5}$

(d) the Carrington Report of 1971, with its acceptance of the feasibility of a two-year curriculum and a clear demarcation between general and advanced law studies; ${ }^{6}$

(e) responses to the articulated concern for deteriorating professional ethics, including various proposals for instruction in ethics; ${ }^{7}$

(f) the clinical education movement of the 1970's and 1980's, with its proposals for broadened skills training and reduced reliance on appellate case review as the basic methodology of legal education; ${ }^{8}$ and,

(g) the law and economics inovement of the 1970's and 1980's, which prompted both a reorientation of soine traditional courses and the inplementation of new advanced offerings. ${ }^{9}$

2. See Schwartz, Economics in Legal Education, 33 J. LEGAL EDUc. 365 (1983); see also Stevens, American Legal Scholarship: Structural Constraints and Intellectual Conceptualism, $33 \mathrm{~J}$. LEGAL EDUC. 442, 446 (1983).

3. See, e.g., Bishop, International Law and the American Lawyer, Mich. STate B.J., May 1949, at 42-43; Carlston, The Teaching of International Law in Law Schools, 48 COLUM. L. REV. 516, 527-33 (1948); Franklin, Needed: More and Better Courses in International Law, 4 J. LEGAL EDuc. 326, 326 (1952); Sohn, The Present Importance of Teaching International Law and Organization, 7 J. LEGAL EDUC. 199, 202 (1954); Vanderbilt, The Responsibilities of Our Law Schools to the Public and the Profession, 3 J. LEGAL Educ. 207, 209 (1950).

4. See, e.g., J. Hall, Comparative LaW and Social Theory 111 (1963) (proposing new sociolegal "humanistic" science premised on reorientation of law and the social sciences to a common subject matter); Dror, Prolegomenon to a Social Study of Law. 13 J. LEGAL Educ. 131, 156 (1960) ("II]t seems necessary . . . to recognize the social study of law as a separate subject which ought to be included in the curriculum of law schools and social science departments.").

5. See, e.g., Pattison, Atavism, Relevancy, and the Hermit: The Law School Today, 29 J. Legal Educ. 62 (1977); Richardson, Does Anyone Care for More Hemlock?, 25 J. LEGal Educ. 427, $432-34$ (1973); Taylor, Wealth, Poverty and Social Change: A Suggestion for a Balanced Curriculum, 22 J. Legal EDUC. 227 (1969); see also Mohr \& Rodgers, Legal Education: Some Student Reflections, 25 J. LEGAL EDUC. 403 (1973).

6. The Carrington Report (1971), reprinted in H. Packer \& T. Ehrlich, New DirecTIONS IN LEGAL EDUCATION 95-328 (1972).

7. See, e.g., Bresnahan, "Ethics" and the Study and Practice of Law: The Problem of Being Professional in a Fuller Sense, 28 J. LEGAL Educ. 189 (1976); Watson, The Watergate Lawyer Syndrome: An Educational Deficiency Disease, 26 J. LEGAL EDuc. 441 (1974).

8. See, e.g., Barnhizer, Clinical Education at the Crossroads: The Need for Direction, 1977 B.Y.U. L. REV. 1025, 1028; Grossman, Clinical Legal Education: History and Diagnosis, 26 J. LEGAL EDUC. 162 (1974); Leleiko, Clinical Education, Empirical Study, and Legal Scholarship, $30 \mathrm{~J}$. LEGAL EDUC. 149, 165 (1979).

9. See, e.g., Gellhom \& Robinson, The Role of Economic Analysis in Legal Education, $33 \mathrm{~J}$. LEgAL EDUC. 247 (1983); Lovett, Economic Analysis and Its Role in Legal Education, 26 J. LEGAL Educ. 385 (1974); cf. Scott, Answers Are More Needed Than Perspectives, 33 J. LEgAL Educ. 285 
Of this list, two developments that have had the most discernible impact on current curriculum reform are the latter two, the embrace of clinical education and instruction in law and economics. As will be seen, an expanded role for each is included in the agenda of current proposals for reform. Other of the proposals left a much less enduring impression. The concept of a two-year curriculum is seldom discussed, even though the third year of law school continues to search for a ineaning and identity. ${ }^{10}$ The fervor of relevance has cooled, reflecting to no small degree the realities of a limited job market that is perceived as rewarding traditionalism. ${ }^{11}$

What did we learn from these earlier efforts at reform? A great deal, it turns out. The responses to the previous new curriculum ideas have confirmed an enduring characteristic of the traditional curriculum-its flexibility. Although some proponents of new approaches enjoy flagellating the traditional curriculum for its rigidity, there are several important respects in which such criticism is quite misplaced. Indeed, although many of the course labels have stayed the same, or at least sound familiar, the curricula at many schools have experienced considerable broadening. Faculties have not wanted for ingenuity in switching the contents of the old vessels.

There are two responses im particular that illustrate the malleability of the traditional curriculum. One of these involves changes in the subject matter of courses that bear very traditional labels. The other involves the phenomenon of the marginal accommodation-the embracing of reform ideas by the relatively low-cost device of adding courses at the margin of the curriculum.

Commentators occasionally decry the fact that law schools by and large continue to offer a first-year curriculum that has changed little in the last fifty years. ${ }^{12}$ In fact, leaving aside occasional experiments by

(1983) (acknowledging the development of an economic "perspective" in legal education, but questioning its efficacy).

10. See Dunne, The Third Year Blahs: Professor Frankfurter After Fifty Years, 94 HaRv. L. Rev. 1237 (1981); Stolz, The Two-Year Law School: The Day the Music Died, 25 J. LEgal Educ. 37 (1973),

11. Elsewhere in this symposium, Abbie Thorner documents the major shift that has occurred in the market for young lawyers. Dr. Thorner observes that the idealism of law students in the 1970 's coincided with a job market in which opportunities were plentiful. In more recent times, economic forces have required that students, and law schools, be more careerist in their orientation. See Thorner, Legal Education in the Recruitment Marketplace: Decades of Change, 1987 DUKE L.J. 276.

12. See, e.g., Horwitz, Are Law Schools Fifty Years Out of Date?, 54 UMKC L. REV. 385, 386 (1986) ("The first year curriculum still seems to convey the idea that the common law is the norm[,] ... perpetuat[ing] the idea that regulations and statutes are abnormal, usually and in fact slightly suspect."). 
venturesome schools, the labels in the first year do appear to be the same: torts, contracts, property, procedure, and criminal law. But a closer look at first-year instruction reveals a much different picture. The basic courses have revealed a capacity to admit of considerable flexibility, not only in substance, but also im methodology.

The course in contracts provides an example. The course acquired a substantial legislative perspective with the incorporation of the Uniform Commercial Code. Whether explicitly recognized or not, the skills imparted in contracts courses built around the UCC can be quite different from those commonly attibuted to Langdellian versions of the offering. ${ }^{13}$ However, the same course label - contracts-can also accommodate a challenging and useful introduction to law and economics. ${ }^{14}$ At the heart of contracts is the exchange. Once there are exchanges, markets cannot be far behind. Contracts rules provide an excellent vehicle for an introductory explanation of the economic effects of legal rules.

In addition, most of the traditional first-year courses are adaptable to new methodologies. As a number of teachers and casebook writers have found, the grasp of the appellate case method can be loosened with relative ease. The subject of contracts, for example, rather steadily admits of the introduction of techniques in problem solving and, for the more venturesome, a first look at clinical approaches. ${ }^{15}$ By the same token, those who seek to introduce inore legal theory into the curriculum will find the basic subjects to be very accommodating. Again using the subject of contracts as the focus, good examples can be found of course materials in which appellate cases have been partially replaced by textual presentations on the nature of contracts and the contracting process. ${ }^{16}$ Finally, contracts is quite accommodating to a legal history perspective. ${ }^{17}$ The influence of early mercantilism, the later industrial revolu-

13. See Friedman, Contract Law and Contract Research (Part I), 20 J. LEGAL Educ. 452, 45657, 459-60 (1968); Speidel, Contract Law: Some Reflections Upon Commercial Context and the Judicial Process, 20 J. Legal Educ. 474 (1968).

14. See, e.g., A. Kronman \& R. Posner, The Economics of Contract Law (1979); R. POSNER, ECONOMIC ANALYSIS OF LAW 79-123 (3d ed. 1986); Kronman, Mistake, Disclosure, Information, and the Law of Contracts, 7 J. LeGAL STUD. 1 (1978); Rea, Efficiency Implications of Penalties and Liquidated Damages, 12 J. LeGAL STUD. 147 (1984); Ulen, The Efficiency of Specific Performance: Toward a Unified Theory of Contract Remedies, 83 MICH. L. REv. 341 , 342 (1984).

15. See, eg., D. Vernon, Contracts: Theory \& Practice (1980).

16. See, eg., R. Summers \& R. Hillman, Contract and Related Obligation: THEory, DOCTRINe AND PRACTICE (1987).

17. Several commentators have argued that the historical context in which contract rules are devised affects the policy choices implicit in them. See, e.g., Horowitz, The Historical Foundations of Modern Contract Law, 87 HARv. L. REv. 917 (1974); Simpson, Quackery and Contract Law: The Case of the Carbolic Smoke Ball, 14 J. Legal Stud. 345 (1985). 
tion, and more modern technological innovation can all be found in contract cases and related legal developments.

Again, the extent of curriculum reform in the past fifteen years has probably been understated, perhaps by a significant degree. Although the labels continue more or less intact, the process of defining the content of courses has becn inuch more dynainic. In many respects, this particular accommodation of form and substance is quite comfortable. The preservation of standard labels appeals to the conservative orientation of the law and probably buys peace with the most skeptical segments of the bar. The capacity for significant substantive change, on the other hand, satisfies urges for creativity and reexamination that are found among the best law teachers and the most thoughtful practitioners. ${ }^{18}$

As an explanation of the recent history of changes in law school curricula, another phenomenon, the matter of accommodating new ideas at the margin, commands particular importance. How did law schools respond to the earlier demands for relevancy, for clinical instruction and the like? Althougl responses varied, a common reaction was to leave the traditional curriculuin intact and to accommodate the demands for change by adding courses at the inargin.

Staffing sucl courses often represented a significant potential cost, but careful planning ensured that the risk of excessive financial comınitment was inanageable. The individuals who taught the speeialized courses often taught in the basic curriculum. Indeed, the internal reward system of the institution usually ensured that substantial contact with the core curriculuin was a desired result. ${ }^{19}$

Clinical education and, to a somewhat lesser extent, law and econonics have been iniportant beneficiaries of the extreine flexibility that is found in the law school curriculum. As an advanced offering, for exam-

18. It should be apparent that issues of curriculum cannot be treated as wholly separate from those of legal scholarship. Law is unlike many disciplines in that faculty members are expected both to engage in sophisticated scholarship and to provide instruction at the most basic level. As long as that strong linkage continues, it is inevitable that new intellectual developments will more quickly find expression in the curriculum. See Symposium, American Legal Scholarship: Directions and Dilemmas, 33 J. LeGal Educ. 403 (1983); Symposium, Legal Scholarship: Its Nature and Purposes, 90 YALE L.J. 955 (1981).

19. Two aspects of the value system of law faculties draw people to the core curriculum. Firstyear courses and some basic upper level offerings are usually perceived as being more lively because of heightened student interest. See, e.g., H. PaCker \& T. EHRlich, New DiRections IN Legal EduCATION 31 (1972); Scholl, Teaching Methods for Professors of First Year Law Students; Helping to Develop Study Skills and a Discussion of the Value of the Not for Credit Midterm, $30 \mathrm{~J}$. LEGAL EDuc. 492 (1980). In addition, courses that either are required-as is true of first-year courses-or draw large enrollments are often seen as relatively more valuable to the institution. In the eyes of some, the professor who teaches such a course partakes of that value. 
ple, a rigorous clinical experience carries a strong justification. ${ }^{20}$ It introduces new skills and broadens the student's educational experience. ${ }^{21}$ From the perspective of a faculty member whose teaching is going to be unaffected, there may be few curricular reasons for resisting proposals for modest chinical offerings. Although problems of accommodation were encountered in the initial period of clinical undertakings, there were most commonly characterized as involving an "appointments" as opposed to a "curriculum" issue. 22

How did the upper level law school curriculum become so accommodating? Of course a variety of factors come into play. But consistently underestimated is the importance of the movement in the 1950's away from extensive mandatory course requirements in the upper level curriculum. ${ }^{23}$ Although the debate at the time seems to have focused on a different question - whether young lawyers would leave law school adequately trained ${ }^{24}$ - the acceptance of an all-elective second- and thirdyear curriculum encouraged creativity and flexibility in advanced offer-

20. See Report and Recommendations of the Task Force on Lawyer Competency: The Role of the Law Schools, 1979 A.B.A. SEc. LEGAL EDUc. \& ADMISsions To B. 15-16, 24 (the "Cramton Report") (recommending increased coursework in the fundamental skills of lawyering and finding that "instruction focusing on lawyer tasks in a simulated or real client clinical setting can provide a powerful method for analytical training" as well as prepare students for real world experience); see also Meltsner \& Schrag, Report from a CLEPR Colony, 76 CoLUM. L. REv. 581 (1976) (describing development and value of clinical program at Columbia University); Meltsner \& Schrag, Scenes from a Clinic, 127 U. PA. L. REv. 1 (1978) (detailing establishment of legal services office at Columbia University).

21. A common complaint about the traditional curriculum is that it is "seriously redundant," persistently focusing on case reading and doctrinal analysis of "very small and rapidly outdated portion[s] of substantive law," instead of providing students through clinical methods of teaching a "broader range of legal analytical methods and skills, which would enable the students more effectively to acquire, understand, and use the substantive law, as they needed it, after they got out of law school." Amsterdam, Clinical Legal Education-A 21st-Century Perspective, 34 J. LEGAL Educ. 612,618 (1984).

22. See, e.g., AALS-ABA COMM. ON GuIdelines for Clinical Legal Education, Clinical Legal Education 112-20 (1980). The Committee recognized the reluctance of law schools to commit tenure-track slots to "a field which is still young, comparatively underdeveloped, and experimental," but concluded that "the importance of clinical legal studies to the law school curriculum requires the application of tenure status to individuals principally teaching in the legal studies curriculum." Id.

Dean Paul D. Carrington has opposed tenure for clinicians, observing that "a university law school that has a very strong commitment to the scholarly enterprise should not tenure a person who does not share that commitment," while Professor Dean H. Rivkin has favored such tenure since "[clinicians] engage in activities virtually indistinguishable from many of their colleagues." Versus: Pro and Con-Faculty Status for Clinical Teaching?, Syllabus, Mar. 1982, at 1, 9.

23. See Prosser, The Ten Year Curriculum, 6 J. LEGAL Educ. 149, 150 (1953); see also Macdonald, Curriculum Development in the 1980s: A Perspective, 32 J. LEGAL EDUC. 569, 570-73 (1982).

24. See Meyers, Curricular Reform: Budgetary Restraints and Responsibility to the Profession, 27 J. LeGAL EDUC. 1, 2 (1975). 
ings. The review of proposals for new offerings could be less exacting because there was less at stake. The question was no longer "is this subject matter something that every good lawyer should know?" Instead, the upper level curriculum came to be seen as something of a marketplace of ideas in which the main concern for any particular entry was whether it would enhance the future lawyer's understanding of his or her work. ${ }^{25}$ Because there is little in the social order that the law does not affect, the movement away from pure utilitariainsm and toward a more general standard of intellectual pertinency greatly expanded the embrace of the law school curriculum.

\section{B. Recent Proposals for Reform.}

The last few years have seen a rather dramatic increase in the number of proposals for curriculuin reform and the willingness of proponents to advocate basic redirections in legal education. Although many proposed changes are anything but marginal, these suggestions occur against the background of the earher broadening of perspectives on the nature of "appropriate" legal training. Clearly there is no one prevailing view of what it means to be a well-trained lawyer. ${ }^{26}$

Several different themes appear in recent proposals. There are a number of suggestions for a more thorough integration of the social sciences. ${ }^{27}$ Others urge that greater attention be given to legal theory, in-

25. This broadened view of the curriculum has not been without its costs, including a loss of coherency. See infra text accompanying notes 87-89; see also Cramton, The Current State of the Law Curriculum, 32 J. LEGAL EDUC. 321, $327-28$ (1982) ("[T] he abandonment of collective responsibility by the law faculties for the curriculum as a whole... and deference to individual faculty autonomy [have created] a law curriculum with no perceptible structure, sequence or organization."); Klare, The Law-School Curriculum in the 1980s: What's Left?, 32 J. LeGal Educ. 336, 337-38 (1982) (noting that students are disabled intellectually in part by "an upper-level experience loosely structured to the point of disintegration, consisting of a melange or hodge-podge of public and private law courses"); Michelman, The Parts and thc Whole: Non-Euclidean Circular Geometry, 32 J. LEGAL EDUC. 352, 354 (1982) ("II]t is next to impossible not to notice what looks like plain deficiencies of coordination in the total array-or disarray-of offerings.").

26. This observation about the lack of unanimity on the definition of an appropriate curriculum may have one dissenter. Geoffrey Hazard fecls that "there would be pretty broad consensus" within the legal academic community and within the legal profession on a definition of an ideal law school curriculum that included: (1) indoctrination in law; (2) training in basic practice skills and techniques; (3) education in relevant nonlegal disciplines; and (4) education in depth in some specific legal problem. See Hazard, Curriculum Structure and Faculty Structure, 35 J. LEGAL EdUc. 326, $327-28$ (1985). The contrary view is based on the extreme breadth in the array of recent proposals for curriculum reform.

27. See, e.g., Priest, Social Science Theory and Legal Education: The Law School as University, 33 J. Legal Educ. 437 (1983); Schwartz, The Future of Economics in Legal Education: The Prospects for a New Model Curriculum, 33 J. LEGAL EDuc. 314 (1983); Zimring, Where Do the New Scholars Learn New Scholarship?, 33 J. LEGAL EdUc. 453 (1983). 
cluding theories of law, rights, and authority. ${ }^{28}$ Proposals for a significant expansion of clinical education can be found, including one that would reorient the basic introductory curriculum around clinical nethods. ${ }^{29}$ Under other proposals, the study of "values," both political and cultural, would assume a more explicit role. ${ }^{30}$ In addition, there are various specific skills and subject areas that are suggested for inclusion in the modern curriculum. Those that have received the most attention recently include statistics, ${ }^{31}$ alternative dispute resolution, ${ }^{32}$ and techniques in written and oral communication. ${ }^{33}$

The array of recent proposals is sufficiently varied to elude most efforts at achieving a comprehensive classification scheme. There are, though, some discernible themes. For example, there is one issue that provides a basis for preliminary differentiation. In general terms, the issue is: Will a particular reform result in a change in the basic structure of legal education, or is it one that can be accommodated as a supplement to the existing core? Proposals for adding particular courses often raise interesting questions of "how to" and "why." But typically these proposals represent bittle challenge to the existing curriculum structure. ${ }^{34}$ Like the "relevance courses" of the 1970's, they can be added to the advanced curriculum with limited intrusion and, if properly planned, lim-

28. See, e.g., Cramton, supra note 25, at 330-32 (suggesting that "the law curriculum is neither sufficiently theoretical nor sufficiently practical"); Klare, supra note 25 , at 343 ("Emphasis on theoretical learning in the law-school curriculum would serve to bring a sense of totality and coherence to students' understanding of the cominon-law experience.").

29. See Amsterdam, supra note 21, at 617-18.

30. See, eg., Halpern, On the Politics and Pathology of Legal Education, 32 J. LEGAL EDUC. 383, 387 (1982) ("[T]he emphasis on case law effectively precludes consideration of fundamental questions about law."); Kershen, Humanitics and the First-Year Curriculum in Law School, 34 OKLA. L. REV. 790, 792-93 (1981) (proposing that "the entire first year of law school be devoted to the study of law as a humanistic disciphine" so the student "can then view law school as part of the unending huinanistic quest for a fuller and deeper understanding of ourselves, society and history"); Lesnick, Legal Education's Concern with Justice: A Conversation with a Critic, 35 J. LEgal Educ. 414, 420 (1985) ("[T]he presence in the law schools of tears, prayers, anger, despair, division, and feelings of oppression, while perhaps not symptoms of success in constructing a quality legal education, are symptoins of struggle over exactly the subjeets that it is essential to struggle over.").

31. See Kaye, Thinking Like a Statistician: The Report of the American Statistical Association Committee on Training in Statistics in Selected Professions, 34 J. Legal Educ. 97, 100-02 (1984) (summarizing recommendations for educating law students in statistics).

32. See Sander, Alternative Dispute Resolution in the Law School Curriculum: Opportunities and Obstacles, 34 J. LEGAL EDuc. 229, 236 (1984); see also Developments in Alternative Dispute Resolution, 37 J. LEGAL EDuc. 26 (1987).

33. See Vernon, Education for Proficiency: The Continuum, 33 J. LEGAL Educ. 559, 563-65 (1983).

34. See, e.g., Kaye, supra note 31 , at 100-02 (noting various nonobtrusive ways to meet the recommended two-semester-hours equivalent of a basic course in applied probability and statistics). 
ited cost. 35

Other proposals, however, intend that a wholly new order be imposed on legal education. In their most extreme forms, the proposals call for an abandonment of traditional course divisions and the establishment of a new array of offerings structured either around aspects of the legal process (as opposed to subject matter) ${ }^{36}$ or around a methodology. ${ }^{37}$ Many of the structural proposals also assume the obsolescence of traditional faculty members, or at least an obsolescence of their skills. ${ }^{38}$ Other versions are milder, incorporating suggestions for reordering course topics, but with an emphasis on skills more readily adaptable by most existing faculty members.

Proposals for expanding the role of the social sciences illustrate the varying degrees of change that are being urged. Most good law schools have added faculty who are trained in one of the social sciences and who teach in the basic curriculum. ${ }^{39}$ Indeed, some of the most significant recent writing about law and the legal system has come from this group. One secondary contribution of this scholarship is to suggest the respects in which traditional lawmaking and law materials operate oblivious to the substantial contribution of other disciplines in explaiming our social order. ${ }^{40}$

Most people who have thouglit about the law scliool curriculum would agree with the general notion that more needs to be done to accommodate the learning of the social sciences. How the accommodation is to be made is another matter, however. A variety of proposals have been put forth. For example, there has been a specific proposal to reorient the entire first-year curriculum around a law and economics perspective, with additional offerings that would explain, respectively, empirical methodology and the influence of culture on law. ${ }^{41}$

35. See Hiner, Pedrick \& Reppy, Should Permanent Faculty Teach First-Year Legal Writing? A Debate, 32 J. Legal Educ. 413 (1982).

36. See Schwartz, supra note 27 , at 315-16.

37. See Amsterdam, supra note 21, at 616-17.

38. See Auerbach, Legal Education and Some of its Discontents, 34 J. LEGAl Educ. 43, 71-72 (1984).

39. See Zimring, supra note 27 , at 453 n.4 (calling for more training in empirical research for aspiring law professors and criticizing law schools for taking the "Noah's Ark" approach: "Get two but no more than two of the best of everything.").

40. See Bok, A Flawed System of Law Practice and Training, 33 J. LEGAL EDuc. 570, 581-82 (1983) (warning that law schools "ignore the social sciences at [their] peril," for social science techniques are growing increasingly refined and probably would help improve the legal system); Gee \& Jackson, Bridging the Gap: Legal Education and Lawyer Competency, 1977 B.Y.U. L. REV. 695, 877 (1977) ("[R] eality dictates that there be an increasing interest in interdisciplinary programming as a closer nexus between law and other allied disciplines naturally develops.").

41. See Schwartz, supra note 27, at 315-16. 
Perhaps the most venturesome proposal comes, presumably with a bit of hyperbole, from George Priest. ${ }^{42}$ He suggests that the law school should become a mimi-university within the university and be structured around a number of small graduate divisions, each representimg one of the social sciences: "The law school curriculum will come to consist of graduate courses in apphied economics, social theory, and political science." 43 Both teaching and learning will be increasingly narrow.

Others see the need for greater integration of the social science perspective but propose an accommodation on much milder terms. Bob Summers, for example, advocates the continuation of present advanced offerings im the social sciences and the addition of a required first-year course deftly entitled "Fact, Social Science, and Law."44 Proponents of other forms of accommodation can be found, including those who suggest that students be immersed in apphications of empirical methodology. 45

Many proposals assume that the nature of law school supported research will be expanded to include the research endeavors of the faculty members trained in the social sciences. ${ }^{46}$ The law school presumably will be prepared to provide or arrange for the funding of empirical research, a venture that has not previously been common in the law school's support endeavors and which surely has significant budgetary implications.

As can be seen, the important curriculum question to be asked is not simply whether there should be a greater accommodation of social sciences in the law school curriculum. The more difficult issue goes to how thorough and complete should be the integration. The array of choices invites a rigorous inquiry into this issue.

Proposals for an increased role for clinical education present a similar issue. Many begin as suggestions for a radical reorienting of the law school curriculum with significant resources shifted to clinical offerings and away from traditional instruction, which is frequently perceived as

\footnotetext{
42. See Priest, supra note 27.

43. Id. at $440-41$.

44. See Summers, The Future of Economics in Legal Education: Limits and Constraints, $33 \mathrm{~J}$. LEgAi Educ. 337, 353 (1983).

45. See Hazard, supra note 26 , at 330 .

46. See Bok, supra note 40 , at $581-82$ ("If the necessary research is to go forward, legal scholars must organize it and participate in it, albeit with the aid of interested colleagues from other disciplines."); Hazard, supra note 26, at 330 (implementation of Hazard's ideal curriculum would "require that the law school itself have a continuously ongoing program of social science research, or that it be intimately connected with other departments that were so engaged and into which law students could be introduced as collaborators").
} 
redundant and repetitive in terms of skills that are conveyed. ${ }^{47}$ Although education in the clinical setting is recognized as much more expensive than traditional offerings, it is seen as a more certain route for ensuring that prospective lawyers develop perspectives and skills that will continue to have value as their practice endeavors mature. But again, a decisionmaker can modulate the degree of its agreement with the premise of such a curriculum change. Although there are proponents for the accommodation of clinical techniques in the basic structure of the law school curriculum, a law school (or the decisionmaker directing its future) may choose reforms of a inuch inore marginal nature. ${ }^{48}$

The two exainples given above are subject matter specific. Not all proponents of basic curriculuin reform would agree about the desirability of building the curriculuin around a single topical theine. Some proposals can be seen as a reaction to the recent tendency toward the marginal accommodation of new courses and the uncritical continuation of traditional offerings. In the view of soine commentators, the end product of such a process is a loss of colherency.

Roger Cramton has perhaps done the most to call attention to the disarray in the present curriculum and to propose a comprehensive alternative. ${ }^{49} \mathrm{He}$ calls for a curriculum that is both more theoretical and more practical. More attention would be devoted to exploring the theoretical foundations of basic legal relationships. In addition, the perceived narrowness and redundancy of the skills conveyed in traditional courses would be cured by a grcater einphasis on skills thought to be inore useful in a professional setting.

An inportant ingredient in Professor Crainton's system is a inore authoritative role for the law school administration..$^{50}$ While the present

47. See Amsterdam, supra note 21, at 615-18; see also Holton, Outline for an Integrated Law Curriculum, 24 J. LEGAL EDUC. 195 (1972) (outlining a four-year law school curriculum with the fourth year devoted to a "clinical expression of learning acquired in the first three years").

48. Indeed, commentators recognize that clinical courses are popular because they can be added to the law school curriculum without major restructuring. As Herbert Packer and Thomas Ehlrich note, "clinical education lends itself to being a separate activity; it is by nature removed from the law school and up to the present has been essentially extra-curricular. Thus small clinical programs can be added 'on the side' to the curriculum, necessitating no fundamental changes in the life of the law school nor, more significantly, in the lives of most of the faculty." H. PACKER \& T. EHRLICH, supra note 19, at 37-38. E. Gordon Gee and Donald W. Jackson note that tension only arises between academicians and clinicians when there is "an attempt to integrate clinical legal education into the curriculum with all of the appropriate trappings." Gee \& Jackson, supra note 40 , at 877.

49. See Cramton, supra note 25, at 327-29; Cramton, Lawyer Competence and the Law Schools, 4 U. ARK, LITTLE ROCK L.J. 1 (1981).

50. See Cramton, supra note 25, at 334-35. One facet of this more authoritarian role is stated rather unmistakenly in Professor Cramton's appraisal of the extent to which the existing "student culture" of law school inhibits curriculum change: 
law school curriculum embraces a central theme of faculty autonomy and student discretion in choosing upper level courses, the Cramton proposals assume an emphasis on coordmation, sequencing, and predetermined course content that will necessitate a significant increase in institutional regulation. ${ }^{51}$

\section{CuRriculum Reform IN CONTEXT}

Judging from the delightful array of recent writings on curriculum reform in the Journal of Legal Education, it is much more fashionable to talk about the nature and scope of potential reforms than to address the more pragmatic concerns that will determine whether they are adopted. Indeed, it is not uncommon for a proposal to be put forth without comment on its costs or its effects on existing resources, especially existing faculty resources. But the "process" of curriculum reform will have a significant impact on the configuration of any reforms ultimately accepted. Thus, while the current reform agenda is quite full, many of the proposals lose their luster when they confront the constraints that define the present potential of legal education.

We now turn our attention to the three elements that are likely to be most influential in the present debate on reform. These are the role of faculty autonomy, the likely continuation of the preference for flexibility, and the consideration of costs.

\section{A. Faculty Autonomy.}

Faculty meinbers not involved in curriculuin reform might be a bit surprised at what is said about them by those who are. On those relatively rare occasions when a question is raised as to why a particular set of reforms is not adopted, a common response is that the faculty controls the curriculum and the faculty resists change. The faculty as a curriculum setting body is seen as being rather conservative, protective of their existing prerogatives and reluctant to innovate. ${ }^{52}$ This rather uncompli-

[T]he fact that many students view law school as an obstacle course on the way to an initial law job creates practical and political problems for curriculum change. But these difficulties can be surmounted with patience, seduction, and, if necessary, brute force.

Id. at 333 .

51. Other commentators have perceived a "shapelessness" in the modern curriculum. See e.g., Michelman, supra note 25, at 355-56 ("[Q]uestions of curriculum . . . are finally the responsibility of the faculty as a whole to try to deal with."); Sandalow, The Moral Responsibility of Law Schools, 34 J. LEGAL EDUC. 163, 164 (1984) (commenting that the state of the curriculum is "symptomatic of ... the seeming inability of law schools to address fundamental issues concerning the goals of legal education" and that recent curricular innovations "suggest only that law schools are prepared to accept, willy-nilly, whatever new ideas may be advanced about the educational needs of students").

52. Commentators have offered various explanations for law faculty intransigence. Roger Cramton observes that "[s]ince the national law schools are also sprinkled with teachers who are 
mentary view of the faculty's role is the one most frequently given for why broad scale reforms have not been forthcoming. .

It is true that law faculty members presently enjoy a great deal of autonomy. It is also true that any intrusion into present prerogatives is likely to encounter resistance. By the same token, however, it is far from clear that faculties are accurately characterized as too resistant to innovation. ${ }^{53}$ Moreover, there may be strong reasons of educational policy to preserve a wide berth for faculty prerogative. The climate for creativity that is thus created may be more valuable than a more tightly drawn curriculum structure.

The accuracy of the characterization of the faculty as unsyinpathetic and obstructionist can be questioned. Under one view, the recent historical record is quite to the contrary. Recent experience with new courses reflects sometlimg approaching phenomenal growth in terms of the methodology and subject matter that now yields law school credit. ${ }^{54}$ Indeed, many of the current topics vying for increased attention in the curriculum-law and economics, other social sciences and their methodologies, clinical education-have met with initial faculty acceptance. $^{55}$ The same is true of other items on our hist of earher reforms.

threatened by anything new, disdainful of the practice of law, and inclined to be intolerant of any research other than the manipulation of doctrine or abstract theory, progress has been slow." Cramton, supra note 25 , at 326 . He suggests that curricular innovation is slow because responsibility for change rests largely on the faculty of the national law school who "have the least incentive to develop new and better ways of teaching lawyer skills since their graduates, unlike those of the local schools, generally receive a good on-the-job apprenticeship in some lawyering skills in the major law firms." Id.

Geoffrey Hazard blames the nature of law school faculty selection for the lack of innovation in the law school curriculun. He finds "that faculty select faculty, that faculty individually have tenure and collectively have constitutional authority over the curriculum, and that in these respects all members of the faculty are equal. ... Thus, with law school faculty being equal, law school courses are all equal, and the curriculum does not change." Hazard, supra note 26, at 332.

Warren Schwartz finds an econounic explanation for faculty intransigence:

[L]aw professors have the opportunity to increase their nonmonetary income by choosing a curriculum they prefer. They can exercise this power either by lowering their personal costs or by increasing their benefits. They can reduce their costs by resisting curricular change which would make more costly the perfornance of their duties. Thus a curriculum that involves systematic incorporation of economics or other disciplines inay be rejected in favor of one which permits continued utilization of existing hunian capital. In general, then, faculties will have an incentive to resist changes which increase the costs of perfonning their teaching responsibilities.

Schwartz, supra note 27, at 334.

53. As Warren Schwartz recognizes, good faculty attach a high value to study and learning. Schwartz, supra note 27 , at 334 . These qualities will include a preference for the innovative and the insightful, an orientation that should extend to issues affecting the curriculun.

54. The expansion of the modern law school curriculum into previously unexplored areas can be seen as the countervailing virtue to the complaints that have been raised about incoherency. See supra note 51 and accompanying text.

55. See, e.g., Gellhorn \& Robinson, supra note 9, at 247; Schwartz, supra note 27, at 334. 
This behavior hardly bespeaks unthinking resistance to innovation.

There is another much different reason for doubting the sufficiency of explaining the failure of curriculum reform proposals by degrading the faculty's role. Faculty autonomy, even if it conforms to the low characterization given it by its critics, must surely be a two-edged concept. While a faculty meinber-under the critic's view-will not readily give up his or her prerogatives, by the same token the individual will be relatively unconcerned by what goes on in other bailiwicks. ${ }^{56}$ The tolerance of extreme eclecticism in the advanced curriculum seens to confirm this.

An implication of this analysis is that one would expect relatively hittle resistance to competing models of instruction within a single faculty. Again, there is a good deal of evidence to confirm this high level of tolerance. In some cases, the competing model is explicitly different, as in the case of the alternative Stanford curriculum..$^{57}$ In others, it is as simple as the acceptance of courses that vary widely in content but bear the common label of "torts" or "property" or the like. The transformation of the subject of "contracts" into an offering of highly variable content was possible precisely because the collective faculty does not exercise a tight hand in curriculum matters. ${ }^{58}$

A final point is of more general significance and that is that a preference for faculty autonomy over tight curricular control inay be quite defensible. Such autonomy has its virtues and these may well be deeined by neutral parties to be of a higher order than the favorite reform proposals of a few. At a minimum, the question of reform versus continued autonomy should be seen as a hively one.

56. Roger Cramton, who is otherwise rather critical of the faculty's role in curriculum planning, accepts the basic point that faculties have been more indifferent than possessive. He has observed that "the Lone Ranger theory of legal education, almost universally observed in the United States, involves an implicit compact (some would call it a conspiracy) among faculty members; 'you do your thing in your course as long as I am permitted to do my thing in mine." "Cramton, supra note 25 , at $327-28$. This agreement leads to widespread ignorance among faculty members about their school's curriculum. "1n terms of content, no one knows whether the law of standing, for example, has been omitted entirely or taught once, twice, three times, or even more. In terms of method, [faculty members] know little about how [their] colleagues teach and what the effect of their efforts is on students as a whole." Id. at 327.

57. The Stanford experiment, called Curriculum $B$, is offered to a small group of students as an alternative to the standard first-year curriculum. Curriculum $B$ involves more fully intergrated versions of the traditional first-year offerings, plus shorter courses providing perspectives from economics, history, and the social sciences. See Stan. Law., Winter/Spring 1979-80, at 46, col. 1.

Harvard Law School has attempted a more limited experiment in its first-year curriculum. Instructors in a group of basic first-year courses hold weekly multidisciplinary classes and periodic bridge sessions to emphasize the connections between their subjects. See Harv. L. Rec., Oct. S, 1984, at 7, col. 1; Harv. L. Rec., Mar. 2, 1984, at 3, col. 1.

58. See supra text accompanying notes 15-17. 
Most of the models for pervasive curriculum reform assume, typically without elaboration, that there will be more thorough, more detailed administrative control of faculty work effort than at present. Indeed, a doubtful feature of some proposals is their implicit assumption of an exquisite fine-tuning of the content and sequencing of courses. ${ }^{59}$ Again, though, virtually no attention is given to the trade-offs of such reginentation.

A very likely consequence of such control, however, is a significant loss in creativity and innovation. In a curriculum that is less centrally directed, considerable freedom exists to test new approaches and seek new insights into a subject area. ${ }^{60}$ It is understandable that some faculty meinbers view this wide range of prerogatives as a virtue worth preserving.

An impressive feature of the law and econormics moveinent, for exainple, is the extent to which it was a spontaneous adaptation of new ideas. Most faculties have in their midst individuals with rather traditional credentials who first examined, then tested, and then adopted a version of the law and economics perspective. ${ }^{61}$ Not infrequently, this adaptation occurred under the guise of a course load in which the basic labels remained unaltered. It is quite imaginable that in a different era where course content was more tightly controlled, the embrace of economic analysis would have been much delayed.

Stated another way, inost proposals for a fundamentally restructured curriculum fail to give us a reassurance that the better curriculum idea of the 1980's will not be the horse collar of the twenty-first century. A lack of fervor for increasing the bureaucracy of legal education should not necessarily be seen as imtransigence.

\section{B. The Adaptability of the Present Curriculum.}

An attraction of the present law school curriculum is its capacity for absorbing new ideas. Complaints that the curriculum is excessively rigid

59. For those who are concerned about a perceived lack of coherency in the modern curriculum, there would appear to be no choice but to impose more exacting regulation. See Cramton, supra note 25 , at $327-28$. Even more venturesome is the implicit assumption underlying the calls for more instruction in values and political premises. See, e.g., Halpern, supra note 30, at 391-94. Such instruction can occur only if there is first an agreement as to the values to be conveyed. There is little reason to believe that a consensus on this point will emerge. In the absence of consensus, some significant authoritarian intrusion leading to the selection of preferred values would be necessary.

60. For a generally approving view of the capacity of law schools to generate and enhance new ideas, see Hughes, The Great American Legal Scholarship Bazaar, 33 J. LEGAL Educ. 424 (1983).

61. See Lovett, supra note 9, at 388-93. It is not uncommon for commentaries on legal education to include assertions that the curriculum has not changed in several decades. See, eg., Horwitz, supra note 12, at 386. As earlier suggested, however, this perspective may understate the extent to which substantive curriculum changes have been masked by a continuation of historical forms. 
and unchanging may simply be incorrect. As earher discussed, traditional course offerings have proven amenable to new inethodologies and new substantive perspectives. ${ }^{62}$ In the same vein, the traditional curriculuin has shown a great capacity to accept additions at the margin.

The period from 1965 to 1985 was one of significant change in the nation's social order. Inevitably, it was also a period of great change in the law. Even though there are signs of strain and a few tattered edges, the traditional curriculum allowed law schools to weather rather well the significant cycles of the past twenty years. ${ }^{63}$ One can imagine other curriculuin approaches-for example, one that rehed on two or two-and-ahalf years of required courses-that would not have endured so well.

It is quite imaginable that when faced with proposals for the curriculum that are narrower and more highly focused, law faculties will continue to prefer the inalleability of the traditional model. The boldest of the present proposals--those that would organize the law school curriculum around a single subject matter or single perspeetive-inevitably seem to be less flexible, especially when the degree of change in the law over the past twenty years is projected into the future. ${ }^{64}$ It may well be that the lessons of law and econormics will not seem as urgent in the early twenty-first century as they do now. 65 At a minimum, it is understandable that faculties might be hesitant to cast their lot with a single, coinprehensive perspective.

62. See supra text accompanying notes 12-17.

63. The period from 1970 to 1973 may provide the best examples of the adaptability of the curriculum. That era was rather unusual in that pointed complaints about legal education came from students, a type of activism not witnessed on such a grand scale either before or since that time. The students' concerns ranged from dissatisfaction with the substantive coverage of the curriculum to complaints about tile values that were being conveyed in traditional courses. Law schools used various approaches in responding to these issues. See Johnstone, Student Discontent and Educational Reform in the Law School, 23 J. Legal Educ. 255 (1970); Pattison, supra note 5, at 63-64; Richardson, supra note 5, at 432-34. The most inportant point, however, is that the adaptations came with relatively little upheaval and even less cost to the basic curriculum design.

64. The present proposals for curriculun reform include several that give plausibility to the concern about inflexibility. George Priest's proposal for mini-graduate departments in the social sciences excludes a number of alternatives that might later be desirable. See Priest, supra note 27, at 441. Some law and economics proposals have a similar characteristic. A singular perspective requires something of a leap of faith, especially for those who believe that a human perspective that is more than simply econonic influences how disputes arise and get resolved. See, eg., Kelman, Misunderstanding Social Life: A Critique of the Core Premises of "Law and Economics," 33 J. LEGAL EDUC. 274, $277-78$ (1983); Summers, supra note 44, at 344-48.

65. Bob Summers gives a rather thorough ordering of the reasons why many find that an economic perspective provides an incomplete explanation for the nature of law. Among these reasons is a failure to take account of human values that have no ready econonic translation. See Summers, supra note 44, at 342-52; see also Kelman, supra note 64, at 274 ("[Economic analysis of law] has served a mystifying, obscuring, function [and has misled] lawyers and law students through its simplistic elegance not only into what strikes me as a relatively minor sin-misunderstanding law-but a rather serious one as well-misunderstanding social life in general."). 
The element of adaptability in the curriculum also coinplements the virtuous side of faculty autonomy. As noted, such autonomy can foster great creativity and indeed it has in recent years. But for new perspectives on the nature of the law to get fullest expression, extreine rigidity in the curriculum must be avoided.66 Sometimes subject matter and methodological innovations occur in sinaller steps. At other times, they appear as grand experiments. In each case, the impulses toward such creativity are encouraged if there is flexibility in the curriculum structure. Again, not all of the new idcas for curriculum reform will contimue this flexibility and thus there are differing views on the value of forsaking the existing preference for a looser structure.

\section{The Issue of Costs.}

The issue of costs will play a pronment role in the debate on curriculum reform. Most faculty inembers are aware of the significant cost difference between various methods of instruction. And it does not take a great deal of thought to see that one of the most powerful forces driving the traditional curriculum structure is its relative cost advantage. For example, in a school with an enrollment of 600 students, the entire firstyear instructional burden can be inet by the equivalent of shightly more than six of the thirty faculty-years of teaching output that are likely to be available. ${ }^{67}$ Decreasing course enrollment by one-half or by threefourths consumes tremendous additional resources. ${ }^{68}$ Despite the obviousness of this point, it typically receives no attention or only a passing mention in discussions of reform. ${ }^{69}$

To some extent, this avoidance of the cost issue is understandable. Faculties typically play a minor role in overall budgetary planning. ${ }^{70}$

66. See Kelso \& Kelso, Legal Education's Failure: A Broader Horizon or a Narrowing Window?, 59 WASH. U.L.Q. 661, 682-83 (1981).

67. The law school model contrasts rather sharply with that used in most graduate programs, where seminars, supervised research, and mentorships are the norm.

68. Some commentators have expressed doubts about the wisdom of the law schools' embrace of large classes. Edward Cohen, for example, has observed:

The law school world has either permitted, or willingly assisted in, the sublimation or sacrifice of sound educational goals to the inexorable forces of numbers. As long as the law schools permit themselves to be sold as the biggest bargain a University can have, they are doomed to archaic and reactionary educational processes.

Cohen, Toward Radical Reform of the Law School Curriculum, 24 J. LEgal Educ. 210, 211 (1972). See also Velvel, Suggested Improvements in Legal Education, 29 J. LEGAL Educ. 194, 198 (1978).

69. Among recent proposals, one of the notable exceptions in which the issue of costs is explicitly considered is Amsterdam, supra note 21, at 617-18.

70. Monroe Freeman has provided a unique inside view of the personal and political considerations that influence the exercise of university control over law school budgets. Professor Freeman records his reactions to a governance controversy that he encountered as dean of the Hofstra Law School. The budgetary model that fueled the dispute was like that found at many institutions; it 
Moreover, since there is no obvious mechanism for financial accountability, limitations on the faculty's budgetary role may be understandable. But less clear then is the wisdom, and even the plausibility of asking this group to make major expenditure decisions. One would expect-and, I would say, sees-a great deal of indeterminancy in curriculum debates, often because cost issues are only an implicit point and thus only as demanding as the mind's eye chooses to make them.

This particular dysfunction in the "process" of curriculum reform explains, in large part, the lack of direction that characterizes much of the present discussion. In a more highly regulated world, the editors of the Journal of Legal Education might insist that each new article on curriculum reform be accompanied by an Economic Impact Statement. In the absence of such appraisals, the noncommital response of most faculty readers is quite predictable.

In the abstract, it is difficult to deny the value of a student's understanding the basic techniques of social science research and their limitations. A debate focusing on that question is likely to be relatively short. But what is involved in the effective delivery of such instruction? Is Geoffrey Hazard correct that an important lesson of prior experience with social science methods "seems to be that one learns social science by doing it, that is, by actually participating in a researcli project, even if of modest scale"? ${ }^{71}$ If so, the issue of cost is of critical importance. The lesson learned with clinical education and in the few programs for faculty-supervised legal writing is that the cost of individuahized instruction is sizable, and the resources involved will unavoidably be conimitted to the detriment of other, usually quite worthy curricular undertakings. ${ }^{72}$ In light of these costs, one would surely want to know what trade-offs are involved in other lower cost alternatives sucl1 as instruction delivered in larger groups or researcli supervised by persons without faculty status. ${ }^{73}$

Despite the array of proposals on curriculum reform, there are few that approach this level of differentiation. In light of this lack of specification, the generally cool reception given to calls for massive restructur-

assumed that the faculty would have virtually no role in setting financial priorities. See Freeman, Holding Law Schools Hostage, Learning \& L., Spring 1977, at 17, 18-19.

71. Hazard, supra note 26 , at 330.

72. See Gee \& Jackson, supra note 40 , at $891-92$ (discussing the debate over the relative benefits and costs of implementing a clinical program); Vukowich, The Lack of Practical Training in Law Schools: Criticisms, Causes and Programs for Change, 23 CASE W. REs. L. Rev. 140, 147-48 (1971) ("IT]he adoption of a curriculum and pedagogical technique which emphasizes skills and practical training would involve considerable cost, in terms of both the financial expenditure and the sacrifice of time whieh would otherwise be devoted to more theoretical study.").

73. Geoffrey Hazard examines the feasibility of making greater use of non-tenure track instructors for various teaching tasks. He finds that the present structure of law faculties offers a significant impediment to any such innovation. Hazard, supra note 26, at 331-32. 
ing of the law school curriculum is quite sensible. Indeed, there is a respect in which the debate on curriculum reform has yet to take itself seriously.

There is another respect in which the issue of the cost of the proposed methodology becomes important. Presumably imcreased costs in this area would be covered through higher tuition charges; no one has suggested that there are external sources likely to find such changes in methodology so appealing as to be prompted to provide permanent subsidization. ${ }^{74}$ In fact, Ken Pye and John Kramer have elsewhere cogently raised the question as to whether in the face of the present abundance of lawyers any significant increase in state subsidization can be justified, especially at state universities. ${ }^{75} \mathrm{~A}$ careful reading of two other papers in this symposium, Abbie Thorner's paper on placement issues ${ }^{76}$ and John Kramer's examination of financial aid, ${ }^{77}$ may suggest that we are entering an era in which enrollment patterns will show greater sensitivity to costs than has been true in the recent past.

Thus, it will be increasingly difficult to make decisions, such as a choice between implementing low and high cost methodologies, without giving attention to their ultimate financial impact. Often it will be quite unclear that either methodology can be declared inappropriate from an educational perspective. For law schools that find themselves with enrollment trends that are cost sensitive, this uncertainty is likely to favor continuation of the historical practice of large group instruction in the basic subjects. ${ }^{78}$

\section{Implications For the CONTINUINg Debate ON CURRICULUM REFORM}

What are the implications for the law school curriculum in the above assessments of the issues of autonomy, adaptability, and cost? There are several. For one thing, it should be reasonably clear that the

74. There have been various calls over the past 15 years for lawyers and law firms to increase their financial support of legal education. It is notable the these suggestions have gone largely unheeded. See Pye, Legal Education Past and Future: A Summer Carol, 32 J. LEGAL Educ. 367, 377 (1982).

75. See Pye \& Kramer, Solvency and Survival After the Boom-A Different Perspective, 34 J. LEGAL. EDUC. 462, 469-75 (1984).

76. Thorner, supra note 11, at 285 (finding that rising costs decrease the admission pool, increase competition among potential employers, and subject law school admission and placement offices to inquiries about the marketability of their law degrees).

77. Kramer, Will Legal Education Remain Affordable, By Whom, and How?, 1987 DukE L.J. 240 (noting that rising costs may prevent middle class students from attending because of their inability to pay their own tuition or receive sufficient grants).

78. $C f$. id. at 243-44 (suggesting that rising costs will increase the incentive to attend the lowertuition public law schools, thus cutting enrollment at private schools with higher tuition). 
more singular the proposed answer to curriculum reform, the more resistance it will encounter. Although some will dismiss this reticence by faculty meinbers as reflecting only timidity and intellectual curmudgeonism, im truth it may have a much more principled basis. Creativity and adaptability are elements that can properly be valued, even where the cost is a loss of some coherency.

There is, though, another side to these same issues that holds an important lesson for those who favor a significant restructuring. The adaptability of the curricnlum can easily be turned to an advantage. If a proposed change, even an extensive one, is structured to occupy only part of the curriculum -as where it is a parallel, but alternative curriculumthe likelihood of its being adopted imcreases measurably. Again, there are at present several strong exainples of the efficacy of this approacli. ${ }^{79}$ This result can be achieved with minimal disruption of the ethic of faculty autonomy. In the most successful of sucli structures, faculty teacli in them because tliey have chosen to do so. The resulting match between perspective and commitment usually ensures a high level of achieveinent and enthusiasm.

This use of the alternative curriculum approach seems particularly well suited to proposals calling for a more discermible subject matter focus in the law scliool curriculum, most commonly a law and economics or otlier social science perspective. The desired tlieme can be achieved by commanding only a part of law school resources. ${ }^{80}$ In addition, the presence of ongoing alternative approaches sliould encourage a level of examination and debate tliat micely serves to improve each type of offering. Avoided is the all-or-nothing choice that understandably makes a decisionmaker nervous. ${ }^{81}$ Moreover, there is an ever-present basis for comparison that sliould make for inore carefully drawn premises.

79. The Stanford and Harvard experiments are perhaps the most notable recent examples. See supre note 57.

80. A joint degree program, especially one closely tied to a structured course sequence with the same topical emphasis, offers the opportunity for further refinement of the notion of an alternative curriculum. Among the advantages of such an offering is that it uses the existing resources of other divisions of the university and thus potentially may limit overall costs. Cf. Schneller, Interprofessional Legal Practitioners: The Case of the M.D.-LL.B., 27 J. Legal Educ. 324, 324 (1975); Schneller \& Weiner, The M.D.-J.D. Revisited: A Sociological Analysis of Cross-Educated Professionals in the Decade of the 1980s, $6 \mathrm{~J}$. LEGAL MED. 337, 359 (1985).

81. Bob Summers makes this point nicely in a somewhat different context. Professor Summers examines a variety of reasons why law and economics is likely to receive only a modest reception in the law school curriculum. Among these is what he calls the Equal Time argument: "It is said that there are other games in town, e.g., other social sciences or moral philosophy or history or psychology (including social pyschology). The argument is that these subjects have their claims too...." Summers, supra note 44, at 351. Professor Summers believes that the desire to ensure "Equal Time" for these subjects inhibits pervasive curriculum reform. Id. 
Another imphication of the present process of reform is that there must be increased sensitivity to costs. The papers in this symposium by Abbie Thorner and John Kramer should leave no doubt that the future of legal education will be one in which relative cost is an important determinant of policy choices. Proposals for reform that are significantly more expensive will fall our unresponsive ears, except perhaps at the most elite schools. ${ }^{82}$ Although some proponents continue to offer versions of the graduate school model ${ }^{83}$ - where all instruction oceurs with very low student-teacher ratios-the economics of modern legal education may well have rendered these inappropriate.

A matter that requires particular attention is the issue of delivery. What size classes? What degree of faculty involvement? The curriculum proposals put forth to date have done hittle to differentiate between what is optimal and what is feasible in terms of instruction group size. At the level of generality that has thus far prevailed, small group instruction is almost always preferred. But the rather high student-teacher ratios of the traditional model are quite engrained and it is inevitable that any significant movement away from them will involve economic stress. ${ }^{84} \mathrm{Se}-$ rious attention needs to be given to the feasibility of adopting new curriculuin perspectives-especially an orientation in the social sciences-to large group instruction. Indeed, a useful next step in the matter of curriculuin reform would involve further experimentation with different methods of dehvery. ${ }^{85}$ In a very real sense, the victors may be those who perfect the lower cost alternative.

The process of inarginal accommodation will almost certainly continue to have a strong appeal. Indeed, the capacity of the present curriculum to absorb new courses at the inargin means that some proposals for reform raise questions that are of relatively limited import. This is true, for example, for those proposals that involve confined topics such as statistics or alternative dispute resolution. ${ }^{86}$ There will inevitably be questions of appropriateness and availability of resources, but the past twenty years carry an important lesson that many new ideas can be absorbed without fundamental reallocations of resources.

82. Others have recognized that curriculum planning may differ greatly depending on the relative standing, and wealth, of the school involved. See Hazard, supra note 26, at 327.

83. See, e.g., Priest, supra note 27, at 441 ("[T]he increasing specialization of legal scholarship [will lead to] a law school ... comprised of a set of miniature graduate departments in the various disciplines.").

84. See supra note 68 and accompanying text.

85. See, e.g., Greenhaw, Use of Social Science Materials in Teaching Within the Standard Generalist Law Cirriculum, 59 WASH. U.L.Q. 809 (1981); McAninch, Experiential Learning in a Traditional Classroom, 36 J. Legal Edisc. 420 (1986).

86. See supra notes $31-33$ and accompanying text. 
There is, though, a very important downside to the practice of adding courses at the inargin - the risk that such accommodations will be achieved at the cost of coherency in the overall curriculuin. ${ }^{87}$ It is a fair hypothesis that the prominence of reform proposals calling for a central theine or focus in the curriculum are in part a response to the perceptible lack of such a unifying structure in the courses that are presently being offered. ${ }^{88}$ Moreover, the tolerance of an all-elective upper level curriculum says to inany observers that there can be no real confidence as to what students are actually learning and even less assurance that the individual student's course selections follow a coherent pattern. ${ }^{89}$

There is a related concern that will inevitably be brought to the fore. This is the inatter of the cost of the present diversity. We are in an era in which law schools exhibit a great tendency to want to be all things to all people. ${ }^{90}$ Thus, there are those who think that a good law school must have a good climical program, diverse interdisciplinary offerings, a strong international program, and so on. At some point, though, the cost of this approach can become stultifying. And such a result most likely will not have been presented as a clear choice. Rather, because each course or groups of courses is only added incrementally, the costs appear to be small.

There is no simple answer to the pressure that inevitably results from having an accommodating approach to the curriculum. Some schools will choose-and, indeed, some have already chosen-the response of specialization. This pattern has a questionable durability, however, because it runs counter to the lesson of recent years that it is adaptability rather than fixed structures that best respond to the nature of change in the underlying social order.

An alternative approach is for a law school's faculty to develop a thoughtful consensus on the mix of perspectives and methodologies that will be taught. Such an agreement need not, and perhaps should not, be premised on the continuation of any particular existing courses. Rather, it should be accepted that there are almost always a variety of courses through which a particular educational objective can be achieved.

87. See supra note 51 .

88. Cramton, supra note 25 , at 327 ("Except for the fact that one fundamental cognitive skillcase analysis-and one fundamental applied skill-legal research-come early in the law-school experience, the law curriculum has no perceptible structure, sequence, or organization."); Michelman, supra note 25, at 355 ("[There are] problems of coordination, simultaneous and sequential, among course offerings; of shapelessness in the curriculum at least beyond the first year; [and] a lack of any clear sense of direction or progression over the three years.").

89. See Sandalow, supra note 51, at 164-66.

90. See, e.g., Meyers, supra note 24, at 2-3; Velvel, supra note 68, at 199. 
The ultimate purpose of such a consensus on goals would be to provide a measure against which expansion in the curriculun, especially expansion which is simply more of the same, could be checked. The control that is envisaged is a very soft one, however. In particular, it is intended to avoid the heavy regimentation that seems implicit in many of the reform proposals put forth to date. Although such proposals achieve a great deal in terms of introducing colierency, they do so at a rather lieavy cost to other values that have allowed law teaching and legal scholarship finally to exhibit soine vibrancy.

Readers who are being first introduced to issues of law school curricula are likely to be surprised that there is not already a consensus on the overall shape of the curriculum. The fact that there is not is probably the most valid complaint of the critics of faculty autonony. Faculties have indeed shown a strong tendency to add courses incrementally without much thought to the overall contour of the final product. The observation being made here is simply that the economics of legal education will not allow that to continue and thus it is time to begin thinking about how our expansionist tendencies will be remed in. Many of the reform proposals being put forth presently respond to the concern about incoherency. They are thus among the alternatives to be considered. There are others, however, including the inodest suggestion here that in the regulation of the modern law school curriculum, less inay be better.

\section{CONCLUSION}

The number and variety of proposals for curriculum reform sends a needed signal that it is time to rethink the direction of legal education. This call for inquiry should not, however, be taken as an imdication that we are at the brink of a major decision point. Some additional preliminary steps need to be taken to ensure that the debate on curriculum reform is properly focused. In particular, there is a need to reappraise the reasons for the absence of a wholeliearted embrace of the proposals put forward to date. Among the explanations likely to be uncovered is a preference, perhaps a strong one, for many of the values underlying the present arrangements. The adaptability of the contemporary curriculuin and its capacity for encouraging creativity need to be recognized more explicitly.

The next steps in the debate over curriculum reform should also correct the presently prevailing tendency among proponents of new ideas to avoid discussing their cost implications. A good deal turns on the issue of "what can we afford," including such basic questions as who will be excluded froin this particular form of education and with what consequence. Now that the agendat of proposals is reasonably full, it is appro- 
priate to turn attention to matters that deal with feasibility, effectiveness, and durability. 